\title{
LIVER SYNTHESIS FUNCTION IN CHRONIC ASYMP- TOMATIC OR OLIGOSYMPTOMATIC ALCOHOLICS: CORRELATION WITH OTHER LIVER TESTS
}

\author{
Paulo Borini and Romeu Cardoso Guimarães
}

RHCFAP/2970

\begin{abstract}
BORINI, P. et al. - Liver synthesis function in chronic asymptomatic or oligosymptomatic alcoholics: correlation with other liver tests. Rev Hosp Clín Fac Med S Paulo, 54 (3): 97 - 102,1999.
\end{abstract}

SUMMARY: Liver function and its correlation with bilirubin and hepatic enzymes were evaluated in 30 male chronic asymptomatic or oligosymptomatic alcoholics admitted into the psychiatric hospital for detoxification and treatment of alcoholism.

Hypoalbuminemia, lowered prothrombin activity, hypotransferrinemia and hypofibrinogenemia were detected in $32 \%, 32 \%, 28 \%$, and $24 \%$ of patients, respectively. Transferrin was elevated in $8 \%$. Greater prevalence of hyperbilirubinemia was found in patients with lowered prothrombin activity, hypofibrinogenemia, or hypotransferrinemia. No correlation was found between serum bilirubin or aminotransferase levels and normal or elevated albumin levels, time or activity of prothrombin, and fibrinogen levels. Serum alkaline phosphatase was elevated in normoalbuminemics and gamma-glutamyltransferase in patients with lowered prothrombin activity.

Hypoalbuminemia was associated with hypofibrinogenemia, hypotransferrinemia with elevated aspartate aminotransferase or gamma-glutamyltransferase, and hypertransferrinemia with elevation of alanine aminotransferase.

These data indicated the occurrence of hepatic dysfunction due to liver damage caused directly by alcohol or by alcoholism-associated nutritional deficiencies.

DESCRIPTORS: Alcoholism. Liver function tests. Functional disturbances. Liver enzymes.

Alcohol exerts direct toxic action upon the liver, producing structural and functional alterations that may be enhanced by nutritional deficiencies due to inadequate ingestion of food or disturbances in digestion or absorption of nutrients. Alcoholism frequently results in reduced protein synthesis in the liver, leading to deficiency in serum proteins such as albumin, transferrin, and blood coagulation factors.

Social and psychic problems caused by alcoholism usually precede physical medical problems by years. Consequently, alcoholics presenting themselves for treatment of the habit in specialized units compose a group clearly different from those that are received in clinical hospitals or are admitted for treatment of physical problems. The majority of studies evaluating liver functional disturbances in chronic alcoholics refer to the latter, involving patients with exuberant clinical manifestations, with a paucity of observations on phases where symptoms are not evident or are very mild.

This study aimed at: 1) analyzing the behavior of serum biochemical tests that are usually employed for

From "Disciplina de Clínica Médica, Faculdade de Medicina de Marília". Marília - SP Brazil and "Departamento de Biologia Geral, Instituto de Ciências Biológicas, Universidade Federal de Minas Gerais". Belo Horizonte - MG, Brazil. evaluating liver function in chronic asymptomatic or oligosymptomatic alcoholics, and 2) correlating alterations of those functional tests with alterations in bilirubin and liver enzymes.

\section{MATERIALS AND METHODS}

Thirty male chronic alcoholics admitted to the psychiatric hospital for treatment of alcoholic intoxication were considered asymptomatic or oligosymptomatic at the admission, through a physical exam and a clinical structured anamnesis interview ${ }^{5}$. The majority of patients was classified as low or average middle class sub- 
groups. Twenty-five were smokers, and none of them had used illicit drugs or any medicines during the 30 days prior to admission.

After in formed consent, they underwent 24 hours of laboratory exams: hematimetric analyses and biochemical determinations of plasma bilirubins, aminotransferases (aspartate, AST; alanine, ALT), alkaline phosphatase (AP), gamma-glutamyltransferase (GGT), albumin, globulins, fibrinogen, time and activity of prothrombin, iron, total capacity of iron binding, and transferrin saturation index.

Viral antigens were not searched for, and coproparasitologic exams were negative for Schistosoma mansoni eggs.

Data are presented as average + standard deviation. Statistical comparisons employed were chi-squared or one-tailed Fisher's tests for qualitative data and Student's $t$ test for quantitative variables ${ }^{33}$; the $95 \%$ confidence intervals (CI) are shown for some data. Correlation studies were conducted by linear regression, correlation coefficient, and Pearson's significance test 25 . Statistically significant findings ( $p$ $<0.05)$ are noted $(*)$ in the tables.

\section{RESULTS}

Demographic characteristics, feeding and alcoholism patterns, and admission history are presented in table 1 , hematimetric data in table 2 and values of bilirubin and hepatic enzymes in table 3 .

Hypoalbuminemia was observed in ten $(32 \%)$ patients. Hypoalbuminemia was related to low AP activity $(\mathrm{p}<$ 0.001 , CI 19.6 to 42.4). Prevalence and values of other liver enzymes and bilirubin did not differ significantly among groups of normo- or hypoalbuminemics (Table 4).

Time and activity of prothrombin (TAP) was low in ten (32\%) patients.

Table 1 - Demographic characteristics, alcoholism and feeding pattern, and admission history.

\begin{tabular}{lc}
\hline Number of patients & 30 \\
Age (years) & $37.6 \pm 11.6$ \\
Age at onset of consumption (years) & $18.0 \pm 12.2$ \\
Time of consumption (years) & $19.6 \pm 12.2$ \\
Daily intake (grams of pure alcohol) & $323 \pm 116$ \\
Number of admissions (\%) & 47 \\
$\quad$ One & $12(40 \%)$ \\
$\quad$ More than one & $18(60 \%)$ \\
$\quad$ Per patient & 3.1 \\
Feeding pattern (number, \%) & \\
$\quad$ Regularity & \\
$\quad$ Regular & $8(27 \%)$ \\
$\quad$ Irregular & $22(73 \%)$ \\
Meals per day & $2(8 \%)$ \\
$\quad$ None & $18(60 \%)$ \\
$\quad$ One & $7(22 \%)$ \\
$\quad$ More than two 3 (10\%) & \\
\hline
\end{tabular}

Table 2 - Hematologic values.

\begin{tabular}{lcccccc}
\hline & \multicolumn{3}{c}{ Altered group } & \multicolumn{3}{c}{ normal group } \\
\cline { 2 - 7 } & $\mathrm{n}$ & $\%$ & values & $\mathrm{n}$ & $\%$ & values \\
Hemoglobin $(\mathrm{g} \%)$ & 5 & 17 & $11.9 \pm 0.4$ & 25 & 83 & $15.0 \pm 0.7$ \\
Hematocrit (\%) & 5 & 17 & $38.5 \pm 0.6$ & 25 & 83 & $46.6 \pm 1.8$ \\
Mean globular volume $(\mathrm{m} 3)$ & 0 & - & - & 30 & - & $88.9 \pm 2.6$ \\
Leukocytes (per mm3) & 8 & 28 & $11.138 \pm 1.161$ & 22 & 72 & $8.735 \pm 2.331$ \\
Platelets (per mm3) & 0 & - & - & 30 & - & $260.435 \pm 57.335$ \\
Hemosedimentation $(\mathrm{mm} / \mathrm{h})$ & 8 & 28 & $17.4 \pm 1.5$ & 8 & 72 & $5.2 \pm 3.2$ \\
\hline
\end{tabular}

Table 3 - Prevalence and altered values of enzymes and bilirubin

\begin{tabular}{lrrcc}
\hline & $\mathrm{n}$ & $\%$ & values & Reference \\
& 27 & 90 & $30.8 \pm 26.4$ & untill 12 UI \\
Aspartate aminotransferase & 19 & 63 & $23.0 \pm 19.2$ & untill 12 UI \\
Alanine aminotransferase & 26 & 87 & $124 \pm 133$ & $6-28 \mathrm{UI}$ \\
Gamma-glutamyltransferase & 7 & 23 & $67.2 \pm 17.1$ & $13-43 \mathrm{UI}$ \\
Alkaline phosphatase & 7 & 23 & $1.8 \pm 0.11$ & untill $1.2 \mathrm{mg} \%$ \\
Total bilirubin * &
\end{tabular}

* Non-conjugated bilirubin predominated in all cases

Table 4 - Group values and prevalence of altered values of hepatic enzymes and total bilirubin in groups with normal or reduced albumin values.

\begin{tabular}{|c|c|c|c|c|c|c|}
\hline \multirow[b]{4}{*}{ Aspartate aminotransferase } & \multicolumn{6}{|c|}{$\begin{array}{l}\text { Albumin } \\
\text { reference values: } 3.5-5.3 \mathrm{~g} \% \\
\text { Total sample: } 3.7 \pm 0.4 \mathrm{~g} \%\end{array}$} \\
\hline & \multicolumn{3}{|c|}{$\begin{array}{c}\text { Normal } \\
\text { prevalence: } 20-68 \% \\
\text { values: } 3.9 \pm 0.1\end{array}$} & \multicolumn{3}{|c|}{$\begin{array}{c}\text { Reduced } \\
\text { prevalence: } 10-32 \% \\
\text { values: } 3.1 \pm 0.3\end{array}$} \\
\hline & $\mathrm{n}$ & $\%$ & values & $\mathrm{n}$ & $\%$ & values \\
\hline & 19 & 64 & $34 \pm 30$ & 8 & 28 & $22 \pm 9$ \\
\hline Alanine aminotransferase & 13 & 44 & $23 \pm 11$ & 6 & 20 & $17 \pm 4$ \\
\hline Gamma-glutamyltransferase & 17 & 56 & $131 \pm 148$ & 10 & 32 & $64 \pm 20$ \\
\hline Alkaline phosphatase & 5 & 16 & $72 \pm 16$ & 2 & 8 & $41 \pm 10^{*}$ \\
\hline Total bilirubin & 5 & 16 & $1.3 \pm 0.7$ & 2 & 8 & $1.7 \pm 0.2$ \\
\hline
\end{tabular}

Student's t test $* \mathrm{p} \leq 0.05$

Prevalence of elevated total bilirubin was significantly higher for patients with low TAP $(p<0.05)$. GGT average was significantly higher in patients with low TAP $(\mathrm{p}<0.02$, CI 13 to 217). No difference in plasma levels of bilirubin or other liver enzymes was found in groups with normal or 
low TAP (Table 5), and TAP levels were not correlated with those of albumin $(r=0.04, p>0.05)$.

Hypofibrinogenemia was found in seven (24\%) patients. Hyperbilirubinemia was significantly more common in patients with normal fibrinogen levels $(p<0.05)$. Prevalence and elevated values of liver enzymes did not differ in groups with normal or reduced fibrinogen levels (Table 6). Significant correlation was observed between albumin and fibrinogen serum levels $(r=0.50, p<0.02)$ but not between albumin and TAP $(\mathrm{r}=$ $0.04, \mathrm{p}>0.05)$.

Plasma transferrin, measured through total capacity of iron binding,

Table 5 - Group values and prevalence of altered values of hepatic enzymes and total bilirubin in groups with normal or reduced prothrombin activity.

\begin{tabular}{|c|c|c|c|c|c|c|}
\hline \multirow[b]{4}{*}{ Aspartate aminotransferase } & \multicolumn{6}{|c|}{$\begin{array}{l}\text { Prothrombin activity } \\
\text { reference values: } 80-100 \% \\
\text { Total sample: } 82 \pm 11\end{array}$} \\
\hline & \multicolumn{3}{|c|}{$\begin{array}{c}\text { Normal } \\
\text { prevalence: } 20-68 \% \\
\text { values: } 89 \pm 6\end{array}$} & \multicolumn{3}{|c|}{$\begin{array}{c}\text { Reduced } \\
\text { prevalence: } 10-32 \% \\
\text { values: } 74 \pm 1\end{array}$} \\
\hline & $\mathrm{n}$ & $\%$ & values & $\mathrm{n}$ & $\%$ & values \\
\hline & 19 & 64 & $31 \pm 31$ & 8 & 28 & $27 \pm 7$ \\
\hline Alanine aminotransferase & 11 & 36 & $24 \pm 12$ & 8 & 28 & $18 \pm 5$ \\
\hline Gamma-glutamyltransferase & 19 & 64 & $93 \pm 114$ & 7 & 24 & $208 \pm 155^{*}$ \\
\hline Alkaline phosphatase & 5 & 16 & $61 \pm 18$ & 2 & 8 & $69 \pm 24$ \\
\hline Total bilirubin & 2 & 8 & $1.8 \pm 0.1$ & $5^{*}$ & 16 & $1.3 \pm 0.7$ \\
\hline
\end{tabular}

Fisher's one-tailed or Student's t tests $* \mathrm{p} \leq 0.05$

Table 6 - Group values and prevalence of altered values of hepatic enzymes and total bilirubin in groups with normal or reduced fibrinogen values.

\begin{tabular}{|c|c|c|c|c|c|c|}
\hline & \multicolumn{6}{|c|}{$\begin{array}{c}\text { Fibrinogen } \\
\text { reference values: } 2 \%-4 \% \\
\text { total sample: } 2.6 \pm 1.2\end{array}$} \\
\hline & \multicolumn{3}{|c|}{$\begin{array}{c}\text { Normal } \\
\text { prevalence: } 23-76 \% \\
\text { values: } 3.1 \pm 0.8\end{array}$} & \multicolumn{3}{|c|}{$\begin{array}{c}\text { Reduced } \\
\text { prevalence: } 7-24 \% \\
\text { values: } 1.0 \pm 0.4\end{array}$} \\
\hline & $\mathrm{n}$ & $\%$ & values & $\mathrm{n}$ & $\%$ & values \\
\hline Aspartate aminotransferase & 20 & 68 & $33 \pm 30$ & 7 & 24 & $21 \pm 9$ \\
\hline Alanine aminotransferase & 14 & 48 & $23 \pm 11$ & 5 & 16 & $17 \pm 3$ \\
\hline Gamma-glutamyltransferase & 20 & 68 & $137 \pm 144$ & 6 & 20 & $65 \pm 18$ \\
\hline Alkaline phosphatase & 6 & 20 & $60 \pm 23$ & 1 & 4 & $67 \pm 16$ \\
\hline Total bilirubin & 2 & 8 & $1.8 \pm 0.1$ & $5^{*}$ & 16 & $1.3 \pm 0.7$ \\
\hline
\end{tabular}

Fisher's one-tailed test $* \mathrm{p} \quad 0.05$

Table 7 - Group values and prevalence of altered values of hepatic enzymes and total bilirubin in groups with normal or altered transferrin values .

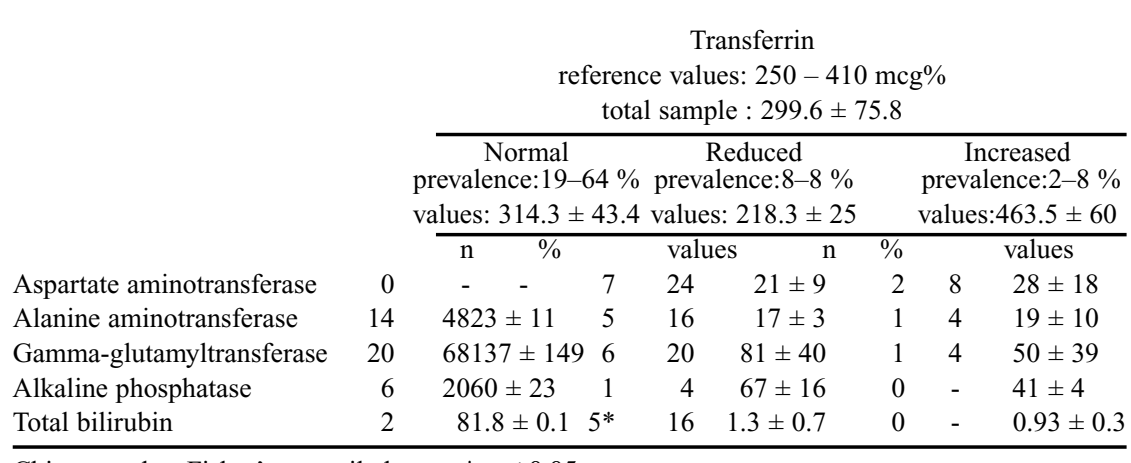

Chi-squared or Fisher's one-tailed tests $* \mathrm{p} \leq 0.05$

was reduced in eight $(28 \%)$ patients increased in two $(8 \%)$ patients. Hyperbilirubinemia was significantly more common in patients with reduced transferrin levels $(\mathrm{p}<0.02)$. No patient with normal transferrin levels showed increases in AST and GGT, while all with reduced levels showed elevation of both enzymes. Prevalence of alteration of ALT or AP did not differ in groups with or without transferrin alteration. In the two cases where transferrin was elevated, AST was altered in both, but ALT or GGT in only one (Table 7). Transferrin alterations were drastic, both altered subgroups being significantly different $(\mathrm{p}<0.001)$ from normal, with CI of 59.2 to 132.0 and 220.2 to -78.2 . Transferrin levels were not correlated with those of albumin $(\mathrm{r}=0.014, \mathrm{p}<0.95)$, prothrombin activity $(\mathrm{r}=0.074, \mathrm{p}<0.72)$ and fibrinogen $(r=0.087, p<0.68)$, but did correlate with serum iron $(r=0.774, p$ $<0.0001)$.

\section{COMMENTS}

Ethanol caloric value is enough to substitute for an important fraction of calories derived from diet components and leads to reduced need for food ingestion 23 . About $8 \%$ of patients in this study reported not having recently having one full meal a day and 60 $\%$ just a scarce daily meal. Ethanol oxidizing enzymes and integrity of hepatocytes depend on dietary high intake of protein and other nutrients. Precursor amino acids are also needed for synthesis of antioxidants such as glutathione, which is drastically diminished in alcoholism ${ }^{34}$. Vitamins $\mathrm{A}$ and $\mathrm{E}$ are other antioxidants protecting cells against ethanol-induced oxidative damage ${ }^{24}$. Inadequate ingestion of proteins associated with diminished hepatic protein synthesis due to direct ethanol action establishes a vicious cycle of progressive failure of liver functions. 
Our study detected such alterations in less than one-third of patients, as revealed by albumin and fibrinogen levels and time and activity of prothrombin. These tests are usually employed for evaluation of hepatocyte synthesis function, and their alterations were not correlated with those of liver enzymes.

In relation to albumin, previous reports are contradictory. Low serum albumin was not related to abnormal sulfobromophthalein retention ${ }^{20}$, but patients with normal levels of total serum protein and albumin/globulin ratios showed altered sulfobromophthalein tests ${ }^{19}$. Deficient protein intake or alteration in absorption or metabolism of amino acids could lead to insufficient availability of amino acid precursors to glutathione and later deficiency of its reduced form. A vicious cycle may be established between lack of substrate and cell damage.

We detected not only correlated prevalence of alterations of albumin and fibrinogen but also hypoalbuminemia usually followed by hypofibrinogenemia. It is likely that such associations could be related to both proteins being synthesized in the same functional zones of liver acini, especially zone 3, where hepatocytes become especially susceptible to aggression, having diminished glutathione reserves and receiving the highest concentrations of some toxic products from drug metabolism ${ }^{31}$. While prothrombin activity depends on fibrinogen, the paradox of not having detected correlation between alterations of them could be explained by normality of other blood clotting factors, especially factor VII ${ }^{18}$.

Transferrin, the main iron transport protein, can be reduced in alcoholics due to liver damage with reduced synthesis or alterations in its metabo$\operatorname{lism}^{27}$. As in another study ${ }^{16}$, average serum transferrin levels were normal.

Plasma transferrin values, regulated in accordance to iron levels, are elevated in iron deficiency. Conversely, reduced hepatic transferrin synthesis is one of the causes of iron defi- ciency, which has been shown in a significant proportion of alcoholics ${ }^{12}$. Nonetheless, our patient sample had normal plasma iron levels. However, among reported cases with high levels of AST, ALT and AP (relative to levels found in normo-ironemics), $40 \%$ were hyperironemic ${ }^{6}$. Increases in serum iron follow development of histologically demonstrable liver necrosis ${ }^{11}$. In all cases with reduced transferrin levels there were AST and GGT alterations, and in both cases with increased serum transferrin, there was concomitant higher ALT levels. The most plausible explanations for these observations would be that reduced transferrin levels was a reflection of liver aggression with functional impairment, while its increase would correspond to the acute phase response ${ }^{29,30}$. In alcoholic hepatitis, leukocytes and macrophages can release cytokines - interleukins and tumor necrosis factor ${ }^{4,17}$ - acting in the regulation of hepatic synthesis of acute phase proteins ${ }^{22}$. Non-correlation between levels of transferrin and fibrinogen, both acute phase proteins, could arise from dependence on different regulators of the production of them.

It is intriguing that the association of low prothrombin activity, hypofibrinogenemia, and hypotransferrinemia with hyperbilirubinemia, in all cases was associated with a predominance of non-conjugated bilirubin. By explanation, various mechanisms could be proposed relating the lack of substrates and hepatocytic dysfunction, isolated or associated in chronic alcoholics. Non-conjugated hyperbilirubinemia could result from increased turnover of plasma bilirubin pools and/or reduction in its clearance. Fasting is a very common phenomenon during of alcoholic intoxication, which occurred in a significant proportion of patients in our study. During fasting, non-conjugated serum bilirubin elevation could be due to various mechanisms, acting in isolation or associated: (1) increase in intestinal absorption of nonconjugat- ed bilirubin from the enterohepatic pool, reasons for which are not yet clear $^{14,26}$; (2) deficient liver uptake and conjugation, a hepatocytic dysfunction that would be similar to that happening in Gilbert's syndrome. Alcohol ingestion in this syndrome causes elevation of non conjugated bilirubin'; (3) Bilirubin flux through the hepatocyte plasma membrane is bidirectional and about $40 \%$ of bilirubin taken up during the first round through the liver is returned non altered to circulation ${ }^{2}$. After uptake, bilirubin is transported to the cytosolic sites of transformation such as by glutathione S-transferase B. This reaction seems important for minimizing bilirubin efflux from the hepatocyte to blood. ${ }^{10}$. Glutathione is drastically diminished in alcoholism ${ }^{34}$. Structural and functional alterations of plasma and organelle membranes of hepatocytes due to lipid peroxidation ${ }^{24}$ and reduction of intracellular glutathione caused by ethanol metabolism-derived acetaldehyde could not only reduce hepatic capacity for clearance of serum non-conjugated bilirubin but also increase the rate of its non conjugated efflux from the hepatocyte.

Some reports have shown that liver is, among all organs investigated, the one losing structural proteins moat quickly and in greatest amounts during fasting, reaching $20 \%$ loss in only 2 days1, but not all serum proteins are affected in the same way ${ }^{21}$. In a previous study $^{7}$ involving patients with a clinical profile similar to this, we observed correlation between prevalence of fasting hypoglycemia and hypofibrinogenemia and indicated that nutritional deficiency would have contributed to impaired synthesis of the protein.

In cases of liver damage, serum albumin concentration decreased slowly due to the protein's in vivo long half-life (about 22 days) ${ }^{31}$, while the half-life of others, such as fibrinogen and vitamin K-dependent factors, are short (1.5 to 6.3 days) ${ }^{32}$. Continuation of fasting during alcoholic intoxication also interferes in serum levels of different proteins. 
Up to a certain period of alcohol abuse, chronic alcoholics develop greater tolerance to ethanol due to increased activity of the oxidizing microsomal system but, after about 30 years of usage, there ensues a decline in tolerance ${ }^{8}$ in such a way that the toxic state is reached faster and admissions for detoxification become each time more frequent ${ }^{9}$. Patients in this study presented themselves for internation about 3 times a year. At admission, ethanol consumption is interrupted, and quality and amount of feeding and vitamin deficiencies are corrected, so that many patients recover from nutritional deficiencies.

Hepatic dysfunction may occur in alcoholics without parallel damage detectable by light microscopy ${ }^{15}$. It is also known that there may not be correlation between the degree of liver fibrosis and plasma levels of hepatic enzymes $^{28}$. Our findings go deeper, indicating that liver cell aggression is not necessarily followed by reduced protein synthesis, since no significant differences were detected in levels of hepatic enzymes, in groups with or without reduction of albumin, fibrino- gen, or prothrombin activity. Nonetheless, the hypothesis has not been ruled out that the lack of correlation of protein and enzymatic alterations might have been due to the former being more sensitive to nutritional deficiencies than to liver cell damage. Studies are needed employing specific methods for evaluation of the nutritional state of patients and more sensitive procedures for testing liver functions.

ACKNOWLEDGMENTS: CNPq, FAPEMIG to RCG.
BORINI, P e col. - A função de síntese hepática em alcoolistas crônicos assintomáticos ou oligossintomáticos. Correlações com outros testes hepáticos. Rev Hosp Clín Fac Med S Paulo, 54 (3): 99104,1999.

A função hepática e suas correlações com a bilirrubina e as enzimas hepáticas foram avaliados em 30 alcoolistas crônicos do sexo masculino, assintomáticos ou oligossintomáticos, internados em hospital psiquiátrico para desintoxicação e tratamento do alcoolismo.

Hipoalbuminemia, hipoatividade da protrombina, hipofibrinogenemia e hipotransferrinemia ocorreram em $32 \%, 32 \%, 24 \%$ e $28 \%$ dos pacientes, respectivamente. A transferrina estava elevada em $8 \%$. Maior prevalência de hiperbilirrubinemia foi encontrada em pacientes com hipoatividade da protrombina, hipofibrinogemia e hipotransferrinemia. Não observou-se correlações entre os níveis séricos da bilirrubina e das aminotransferases e os níveis normais ou diminuídos da albumina, do tempo e atividade da protrombina e fibrinogênio. Os níveis séricos da fosfatase alcalina estavam mais elevados nos pacientes com normoalbuminemia enquanto que os da gama-glutamiltransferase nos com hipoatividade da protrombina. Hipoalbuminemia estava associada com hipofibrinogenemia, hipotransferrinemia com elevações da aspartato aminotransferase e gamaglutamiltransferase, e hipertransferrinemia com elevação da alanino aminotransferase.

Estes dados indicam a ocorrência de disfunção hepática devida a lesão hepática causada diretamente por deficiências nutritivas associadas ao alcoolismo.

DESCRIPTORES: Alcoolismo. Testes funcionais hepático. Distúrbios funcionais. Enzimas hepáticos.

\section{REFERENCES}

1. ADDIS T, POO LJ \& LEW WTH - Protein loss from liver during a two day fast. J Biol Chem 1935; 115: 117-118.

2. BERK PD, HOWE RB, BLOOMER JR et al. - Studies of bilirubin kinetics in normal adults . J Clin Invest 1969; 48(11): 2176-2190.

3. BERK PD \& MOYER C - Hereditary hyperbilirubinemias. In : HAUBRICH WS, SCHAFFNER F \& BERK JE - Bockus- Gastroenterology. $5^{\mathrm{a}}$ ed. Philadelfia, Saunders, 1995. v. 3, p.1906-1930.

4. BIRD GLA, SHERON N, GOKA AJ et al. - Increased plasma tumor necrosis factor in acute alcoholic hepatitis. Ann Intern Med 1990; 112: 917-920.

5.BORINI, P. - Anamnese psiquiátrica e clínica, exame físico e exames complementares estruturados e informatizados para aplicação em alcoolistas. J bras Psiq 1990; 39(5): 250-265.

6. BORINI P \& GUIMARÃES RC - Indicators of inflammation and cell lesion in chronic asymptomatic or oligosymptomatic alcoholics: correlation with alteration of bilirubin and hepatic and pancreatic enzymes. Rev Hosp Clín Fac Med S. Paulo 1999; 54.

7. BORINI P - Metabolismo de carboidratos, lipídios e purina em alcoolistas crônicos assintomáticos ou oligossintomáticos. Correlações entre as alterações metabólicas e os testes avaliadores de agressão de disfunção hepáatica. R Metab Nutr 1996; 3(4): 152-159. 
8. BORINI P - Análise de alguns aspectos do padrão de alcoolismo e suas implicações terapêuticas. Rev ABP-APAL 1991; 13(3): 105-111.

9. BORINI P - Tratamento de alcoolistas em regime de internação hospitalar. Avaliação dos resultados. J Bras Psiq 1993; 42(3): 149-155.

10. BOYER TD - The glutathione S - transferase: an update. Hepatology 1989; 9: 486-496.

11. CONH EM - Pruebas funcionales hepaticas y otros metodos de diagnostico. In: BOCKUS HL - Gastroenterologia. Barcelona, Salvat, 1968. v.3, p.133-185.

12. CONRAD ME \& BARTON JC - Anemia and iron kinetics in alcoholism. Semin Hematol 1980; 17: 149-163.

13. FELSHER BF, RICKARD D \& REDEKER AG - The reciprocal relation between caloric intake and the degree of hyperbilirubinemia in Gilbert' syndrome. N Engl J Med 1970; 283: 170-172.

14. GARTNER U, GOESER T \& WOLKOFF AW - Effect of fasting on the uptake of bilirubin and sulfobromophthalein by isolated perfuse rat liver. Gastroenterology 1997; 113: 1701-1713.

15. GREEN JR - Subclinical acute liver disease of the alcoholic. Aust Ann Med 1965, 14 (2): 111-124.

16. GUPTA S, SLAUGHTER S, AKRIVIADIS EA et al. - Serial measurement of serum C-reactive protein facilitates evaluation in alcoholic hepatitis. Hepatogastroenterology 1995; 42: 516-521.

17. HILL DB, MARSANO L, COHEN D et al. - Increased plasma interleukin-6 concentrations in alcoholic hepatitis. J Lab Clin Med, 119: 547-552, 1992.

18. KLOCZKO J, MIAN M, WOTTUKIEWICZ MZ et al. - Plasma protein $\mathrm{C}$ as marker of hepatocellular damage in alcoholic liver disease. Haemostasis 1992; 22: 340-344.

19. KNOTT DH. \& BEARD JD - Liver function in apparently health chronic alcoholic patients. Am J Med Sci 1966; 252: 260-264.

20. LEEVY CM, PATRYLO I \& DODDY W - Hepatic abnormalities in alcoholics with delirium tremens. Quart J Stud Alcohol 1953; 14: 568 .

21. LIEBER CS - O metabolismo e os efeitos metabólicos do álcool. Simpósio sobre álcool etílico e enfermidades associadas. Clin Med Am Norte 1984; 1: 3-33.
22. MARINKOVIC S, JAHREIS GP, WONG GG et al. - IL-6 modulates the synthesis of a specific set of acute phase plasma proteins in vivo. J Immunol 1989; 142: 808-812.

23 MEZEY E - Liver disease and nutrition. Gastroenterology 1978; 74 : 770-783.

24. MINCIS M - Doença hepática alcoólica. In: MINCIS M Gastroenterologia \& Hepatologia: diagnóstico e tratamento São Paulo, Lemos, 1997. p. 669-690.

25. O' BRIEN PC \& SHAMPO MA - Statistic for clinicians. Mayo Clin Proc 1981; 56: 45-756.

26. PALMER RH - Fasting hyperbilirubinemia [Letter]. Gastroenterology 1998; 115(3): 799.

27. POTTER BJ, CHAPMAN RW, NUNES RM et al. - Transferrin metabolism in alcoholic liver disease. Hepatology 1985; 5(5): 714-721.

28. RIDDER RJ, ARENDS JW, STOCKBRUGGER RW et al. Histomorphometric assessment of fibrosis in advanced alcoholic liver disease. Gastroenterology 1998; 114(4, part 2): [Abstract L0139].

29. SCHREIBER G, TSYKIN A \& ALDRED AR - The acute phase response in the rodent. Ann NY Acad Sci 1989; 557: 61-86.

30. SCHULTZ DR \& ARNOLD PI - Properties of four acute phase proteins: C-reactive protein, serum amyloid A protein, alpha 1-acid glycoprotein, and fibrinogen. Semin Arthritis Rheum 1990; 20: 129-147.

31. SHERLOCK $S$ \& DOOLEY J - Assessment of liver function. In: SHERLOCK, S. \& DOOLEY, J. - Diseases of the liver and biliary system. $9^{a}$ ed. London, Blackwell, 1993. p.17-32.

32. SHERLOCK S \& DOOLEY J - The haematology of liver disease In: SHERLOCK $S$ \& DOOLEY $J$ - Diseases of the liver and biliary system. $9^{\text {a }}$ ed. London, Blackwell, 1993. p.44-61.

33. SOUNIS E - Bioestatística. $3^{\mathrm{a}}$ ed. Rio de Janeiro, Ateneu, 1985.

34. VIDELA LA \& VALENZUELA A - Alcohol ingestion liver glutathione and lipoperocidation: metabolic interrelations and pathological implications. Life Sci 1982; 31: 2395-2407.

Received for publication on the 04/05/99 